Summer 2013

\title{
Introduction: Effects of Global Developments on Gender and the Legal Practice
}

\author{
Gabriele Plickert \\ American Bar Foundation, gplickert@abfn.org
}

Follow this and additional works at: https://www.repository.law.indiana.edu/ijgls

Part of the Civil Rights and Discrimination Commons, Law and Gender Commons, Law and Society Commons, and the Legal Profession Commons

\section{Recommended Citation}

Plickert, Gabriele (2013) "Introduction: Effects of Global Developments on Gender and the Legal Practice," Indiana Journal of Global Legal Studies: Vol. 20 : Iss. 2 , Article 17.

Available at: https://www.repository.law.indiana.edu/ijgls/vol20/iss2/17

This Symposium is brought to you for free and open access by the Law School Journals at Digital Repository @ Maurer Law. It has been accepted for inclusion in Indiana Journal of Global Legal Studies by an authorized editor of Digital Repository @ Maurer Law. For more information, please contact rvaughan@indiana.edu.

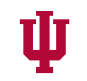

JEROME HALL LAW LIBRARY

INDIANA UNIVERSITY

Maurer School of Law
Bloomington 


\section{Introduction: Effects of Global Developments on Gender and the Legal Practice}

\section{GABRIELE PLICKERT ${ }^{*}$}

The selected papers in this symposium were presented at the 2012 Annual Meeting of the Law and Society Association in Honolulu, Hawaii as part of two panels organized by the International Research Collaborative (IRC) on gender and global legal practice. This emerging research initiative brings together legal scholars and sociologists who examine the relationship between gender and the legal profession in a national and cross-national framework. The purpose of the IRC initiative is to create a dialogue among scholars and professionals both nationally and internationally.

The papers in this symposium provide a snapshot of current issues and developments in legal practice, focusing in particular on women's legal work and their status and experience in a globally transforming legal profession. To date, global analyses still remain quite local and continue to measure and predict developments without stepping outside of domestic settings and familiar research approaches. The contributions to this symposium reflect on these ongoing challenges in local and cross-national research, addressing both opportunities and inequalities that global processes have created for women and men in the legal profession. They serve as a preliminary attempt to underscore the significance of global and local approaches and to further our understanding of emerging changes in the legal profession in various cultures, in an era of globalization.

Globalization more generally implies interdependency among economies around the world, heightens intensity of competition among a large number of players, fosters multinational trading and investment activities, and increases the prevalence of cross-border transactions. ${ }^{1}$

* Ph.D Sociology, Research Social Scientist, American Bar Foundation. Email: gplickert@abfn.org. In collaboration with Carole Silver and Steven Boutcher, I wish to thank Ulrike Schultz for organizing the two panels on the legal profession as part of the International Research Collaborative (IRC) and the editor and staff of the Indiana Journal of Global Legal Studies for the generous support of this printed volume.

1. See generally Thomas Hout et al., How Global Companies Win Out, HaRv. Bus. REV., Sept.-Oct. 1982, at 98.

Indiana Journal of Global Legal Studies Vol. 20, Issue 2 (2013)

(C) Indiana University Maurer School of Law 
The economic, political, and cultural aspects of globalization have promoted a growing connectedness between different societies and cultures, cultivating an interest in and understanding of global communities and cross-national identities. ${ }^{2}$ In other words, globalization refers to the multifaceted and complex processes of worldwide economic, social, cultural, and political expansion and integration, which enable a flow of commodities, commerce, finance, organizations, people, and ideas transnationally across boundaries of cultures, regions, and nation-states. It encompasses growing and dynamic networks of global perceptions, system interdependence, human interaction, and societal transformation, most likely with significant consequences. ${ }^{3}$

While we have an understanding of global processes as some form of interconnectedness and exchange beyond local customs and conventional domestic approaches, the concept of globalization is far more complex. ${ }^{4}$ The focus of global analyses ranges from innovations and modernity to disruption and social inequalities within economic, political, cultural, or geographic processes. Those who attribute "innovative and modern" qualities to globalization emphasize that globalization promotes equality, diversity, and engagement with various cultures, fostering multiple identities and unlimited possibilities. ${ }^{5}$ But globalization has also hardened the opposition of identities. The sanguine developments and outlook of globalization have been subject to critique with respect to reinforcing traditional approaches that intensify social inequalities and discrimination instead of abating them. ${ }^{6}$

2. See generally S. Tamer Cavusgil, Globalization of Markets and Its Impact on Domestic Institutions, 1 IND. J. GLOBAL LEGAL STUD. 83 (1993); Valentine M. Moghadam, Gender and Globalization: Female Labor and Women's Mobilization, 2 J. WoRLD-SYS's. RES. 367 (1999).

3. See generally Esther Ngan-ling Chow, Gender Matters: Studying Globalization and Social Change in the 21st Century, 18 INT'L SoC. 443 (2003); Moghadam, supra note 2; SASkia SASSEN, Globalization and ITS Discontent (1998); Joseph Stiglitz, GLOBALIZATION AND ITS DISCONTENTS (2002).

4. See Mary C. Daly, The Ethical Implications of the Globalization of the Legal Profession: A Challenge to the Teaching of Professional Responsibility in the Twenty-First Century, 21 FoRDHAM INT'L L.J. 1239, 1241 n.1 (1998) (stating globalization means an "active, self-referential, multi-dimensional, economic, political and cultural force"). See generally Hilary Sommerlad, Minorities, Merit, and Misrecognition in the Globalized Profession, 80 FORDHAM L. REV. 2481 (2012).

5. See Sommerlad, supra note 4, at 2485. See generally Eric Neumayer \& Indra De Soysa, Globalization and the Empowerment of Women: An Analysis of Spatial Dependence via Trade and Foreign Direct Investment, 39 WoRLD Dev. 1065 (2011); Deborah Spar \& David Yoffie, Multinational Enterprises and the Prospects for Justice, 52 J. INT'L AFF., no. 2 (1999).

6. See Linda McDowell, Capital Culture: Gender At Work In The City 1.8 (1997); Linda McDowell, Capital Culture Revisited: Sex, Testosterone and the City, 34 
Similarly, feminist scholars reflect on various perspectives on the impact on globalization-some focus on the formation and mobilization of social movements and organizations outside of national opportunities and constraints, ${ }^{7}$ and others underscore the persistence of structural impediments that are significant for women. 8 Consistent with the complex nature of globalization, its impact on women and outcomes in terms of benefits, costs, and predicaments have been mixed..$^{9}$ Overall, the study of globalization has been largely gender neutral, ${ }^{10}$ focusing instead on national developments, and primarily equating global developments with "North American" developments outside of the United States.

Considering the significant influx of women into the legal profession in the United States and around the world, it is essential to include gender in the analysis of global processes. Furthermore, regardless of the fast and significant feminization and the increasing influence of international law firms-with larger firms and increased earnings observed in the U.S. legal profession-this trend has not been adopted concurrently in other settings and countries. There still seems to be a difference in the structure and organization of the legal profession that might also impact gender differences in legal careers in other countries. $^{11}$ We still have little understanding of how national

INT'L J. URB. \& REgIONAL RES. 652, 653-54 (2010). See generally HaRRIET BRADLEY, FRACTURED IDENTITIES: CHANGING PATTERNS OF INEQUALITY (1996).

7. See generally Spar \& Yoffie, supra note 5; Brigitte Young, Globalization and Gender: $A$ European Perspective, in Gender, GLOBalization and DemOCRATIZATION 27 (R.M. Kelly et al. eds., 2001).

8. See generally WOMEN IN THE WORLD'S LEGAL PROFESSION (Ulrike Schultz \& Gisela Shaw eds., 2003); KATHRYN B. WARD, WOMEN IN THE WORLD-SYSTEM (1984); CHRISTA WICHTERICH, THE GLOBALIZED WOMAN: REPORTS FROM A FUTURE OF INEQUALITY (2000); Moghadam, supra note 2; Margaret Thornton \& Joanne Bagust, The Gender Trap: Flexible Work in Corporate Legal Practice, 45 OSGOODE HALL L.J. 773 (2007).

9. See Chow, supra note 3, at 445. See generally Ilse Lenz, Globalization, Gender, and Work: Perspectives on Global Regulation, 20 REV. POL'Y RES. 21 (2003).

10. See generally Chow, supra note 3; Saskia Sassen, Toward a Feminist Analytics of the Global Economy, 4 IND. J. GLOBAL LEGAL STUD. 7 (1996).

11. See generally LAWYERS IN Society: THE CIVIL LAW WorLd (Richard Abel \& Philip Lewis eds., 1988); Richard Abel, Comparative Sociology of Legal Professions, in LAWYERS IN SocietY: Comparative TheORIES 80 (Richard Abel \& Philip Lewis eds., 1989); YveS DEZALAY \& BRYANT GARTH, DEALING IN VIRTUE: INTERNATIONAL COMMERCIAL ARBITRATION AND THE CONSTRUCTION OF A TRANSNATIONAL LEgal ORDER (1996); Richard Abel, Transnational Legal Practice, 44 CASE W. RES. L. ReV. 737 (1994); Gabriele Plickert \& John Hagan, Professional Work and the Timing of Family Formation Among Young Lawyers in US and German Cities, 3 INT'L J. LEGAL PROF. 236 (2011); Sigrid Quack, Legal Professionals and Transnational Law-Making: A Case of Distributed Agency, 14 ORG. 643 (2007); Carole Silver, Globalization and the U.S. Market in Legal Service: Shifting Identities, 31 J.L. \& POL'Y INT'L BUS. 1093 (2000); David Trubeck et al., Global 
differences in legal professional work and organizations impact the careers of lawyers, and-especially women's status and professional opportunities. ${ }^{12}$ Understanding how gender and global processes are linked as causes and effects in various fields of legal practice will produce key insights into the legal profession in the United States, as well as in other countries.

The contributions of authors in this symposium focus on some of the complex and important issues of gender diversity and discrimination relevant to current local and global developments in the legal profession. The articles span topics such as the dual role of gender diversity and globalization in local and global legal practice; ${ }^{13}$ the feminization of the profession and changes in the global supply of lawyers; 14 women's status and careers in light of the economic downturn; ${ }^{15}$ new institutional approaches and opportunities for women in global firms in India; ${ }^{16}$ perceptions of gender differences and diversity and implications for inequalities in Brazilian legal practice; ${ }^{17}$ historical approaches and recent developments in women's status within Chinese legal spheres; ${ }^{18}$ longitudinal approaches to women's turnover in the profession and factors precipitating exits from private practice; ${ }^{19}$ and the role of parenthood in compensation in national law settings. ${ }^{20}$ These contributions provide a look at national and international approaches, featuring a range of countries around the globe.

Restructuring and the Law: Studies of the Internationalization of Legal Fields and the Creation of Transnational Arenas, 44 CASE W. RES. L. REV. 407 (1994).

12. Equally, there is still no comprehensive legal framework for cross-border legal activities at a global level. HAMISH ADAMSON, FREE MOVEMENT OF LAWYERS 160 (1998).

13. See generally Steven A. Boutcher \& Carole Silver, Gender and Global Lawyering: Where are the Women?, 20 IND. J. GLOBAL LEGAL STUD. 1139 (2013).

14. See generally Ethan Michelson, Women in the Legal Profession, 1970-2010: A Study of the Global Supply of Lawyers, 20 IND. J. GLOBAL LEGAL STUD. 1071 (2013).

15. See generally Cynthia Fuchs Epstein \& Abigail Kolker, The Impact of the Economic Downturn on Women Lawyers in the United States, 20 IND. J. GLOBAL LEGAL STUD. 1169 (2013).

16. See generally Swethaa Ballakrishnen, "Why is Gender a Form of Diversity?": Rising Advantages for Women in Global Indian Law Firms, 20 IND. J. GLOBAL LEGAL STUD. 1261 (2013).

17. See generally Maria da Gloria Bonelli, Gender and Difference Among Brazilian Lawyers and Judges: Public and Private Practice in the Global Periphery, 20 IND. J. GLOBAL LEGAL STUD. 1291 (2013).

18. See generally Xiaonan Liu, Chinese Women in Legal Education, 20 IND. J. GLOBAL LEGAL STUD. 1311 (2013).

19. See generally Fiona M. Kay, Stacey Alarie \& Jones Adjei, Leaving Private Practice: How Organizational Context, Time Pressures, and Structural Inflexibilities Shape Departures from Private Law Practice, 20 IND. J. Global LEGAL STUD. 1223 (2013).

20. See generally Nancy Reichman \& Joyce Sterling, Parenthood Status and Compensation in Law Practice, 20 IND. J. GLOBAL LEGAL STUD. 1203 (2013). 
In light of the global and national developments discussed, some vital questions emerge from these papers: What role do women play in the national and global economy and in legal practice? What are the national or international similarities and differences? How will the practice of law evolve, especially for women in an increasingly globalized economy and polity? How far is the process of achieving gender equality advanced or stalled in the legal profession? Do women achieve greater equality in global settings? What can we learn from national versus cross-national comparative studies? Although each article is distinct, the contributions in this symposium raise two important themes.

The first theme explores the discourse on the role of gender diversity and its distinct consequences for men and women in various transnational legal markets. In his article, Ethan Michelson presents a preliminary foray into legal demography by investigating the relationship between bar expansion and the process of lawyer feminization in eighty-six countries. The study models changes in the demand and supply of lawyers within global settings. By exploring various global settings, Michelson compares opportunities and benefits for women and men and underscores women's enhanced access to legal services as a result of the increase in the supply of female lawyers. Steven Boutcher and Carole Silver's article addresses the extent to which women and men benefit from working in global legal markets. The authors investigate the relationship between gender and professional status in elite firms and explore the transitions from local into cross-culturally intertwined legal settings. The analysis reveals links between national and global practice settings in the production of inequalities between women and men.

With respect to gender diversity, opportunities as well as inequalities result from the different ways in which cultural contexts intertwine with global processes. In this framework, global processes are influenced and shaped by national economies, polities, legal standards, and organizations. The study by Maria da Gloria Bonelli investigates Avtar Brah's typology of local perceptions and experiences of lawyers in Brazil; it suggests that men and women are treated differently in Brazilian law firms. Bonelli argues that gendered stratification and segmentation within state bureaucracy and legal organizations impact and uphold gender inequalities in professional practice. A similar argument is made in the article by Xiaonan Liu on developments within legal education and the legal profession in China. Based on surveys, interviews, and archival sources, Liu illustrates how women have been disadvantaged and experienced discrimination in the legal domain by analyzing the conflict between "legal" and "feminine" 
characteristics. In her article, Liu steps outside the local Chinese framework and proposes ways of promoting equality that may eliminate gender discrimination and gender bias within the legal sphere.

In contrast to the previously described developments, Swethaa Ballakrishnen, in her case study, draws attention to new institutional structures in global law firms in India and argues that a newly-established institutional framework offers greater equality and thus facilitates greater latitude for women in global legal practice. The analysis of gender as "structure"21 takes into account individual characteristics, interactional dimensions, and institutional factors to explain how gender-based inequality in the workplace is created and reinforced and how the new territory of innovation potentially promotes equality within the profession. Despite the absence of comparative examples, Ballakrishnen's explorative approach elucidates and presents possibilities for negotiations of gender hierarchies within large global firms.

Extending the focus to global settings provides us with a unique picture that illustrates how women experience and respond to global developments in specific legal markets. The processes of globalization within these transnational and cross-cultural legal settings reveal potential openings and opportunities for women and men. However, it is unclear if these processes may suggest a move toward gender equality and diversity or the dissolution of social categories. ${ }^{22}$

Related to the analysis of gender, the second important theme addresses the status and experience of women in current North American legal settings. These articles speak to the institutional and local economic forces that affect the relationship between gender hierarchies and discrimination in various legal practice settings. The papers recognize the extent to which economic events and institutional structures and cultures regulate local legal settings and uphold gender hierarchies and inequalities.

With respect to challenges pertaining to legal work during the economic downturn, Cynthia Fuchs Epstein and Abigail Kolker explore the changes in status and work experience of lawyers in various legal and nonlegal practice settings. The authors show how economic changes generate advantages as well as drawbacks, created or reinforced by institutional structures that affect differently the experiences and careers of women and men. At this point in time, the long-term effects of these economic changes on the relationship among gender, employment

21. See generally Barbara Risman, Gender as Social Structure, Theory Wrestling with Activism, 18 GENDER \& SOC'Y 429 (2004).

22. See generally ANTHONY GIDDENS, THE TRANSFORMATION OF INTIMACY: SEXUALITY, LOVE AND EROTICISM IN MODERN SOCIETIES (1992). 
status, mobility, income, and personal choices remain unclear. Yet the ethnographic analysis provides an important explorative snapshot of specific outcomes related to these events. In comparison, the articles by Fiona Kay, Stacey Alarie, and Jones Adjei, as well as Nancy Reichman and Joyce Sterling, disentangle work-related factors and personal attributes that influence legal careers of women and men in a longitudinal framework. Kay and her co-authors explore the theoretical underpinnings of job satisfaction, family pressures, and organizational context on departures from private legal practice by women and men. Reichman and Sterling expand the analysis to characteristics of parenthood, credentials, and job performance and show how the divide between the private and public spheres primarily limits the career mobility of mothers. These longitudinal approaches broaden our understanding of the relationship between dimensions of gender and other complex factors in the national practice of law. Concerning the role of global processes for national practice, the authors remain cautious about how global forces potentially impact and relate to locally established structures and the local legal profession more generally.

\section{FROM LOCAL TO GLOBAL -WHERE DO WE GO FROM HERE?}

The increased entry of women into the legal profession around the world has occurred in a multifaceted context of constraints and opportunities. As the authors of this symposium show, long-established organizational and legal structures continue to perpetuate inequalities and discrimination along the lines of gender and other status characteristics. However, growing employment opportunities for women intertwined with national changes and global processes have to some extent enhanced mobility, fostered restructuring of careers, and improved women's access to justice. ${ }^{23}$ Taking this a step further, others also argue that the increasing participation of women in the labor force and in the profession has important implications for changes in gender relations and ideologies within the private sphere. ${ }^{24}$ These perspectives

\footnotetext{
23. See generally Guy Standing, Global Feminization Through Flexible Labor, 17 WORLD DEV. 1077 (1989).

24. See generally Helen Safa, Gender Inequality and Women's Wage Labor: A Theoretical and Empirical Analysis, in PATRIARCHY AND DEVELOPMENT: WOMEN'S Positions at the End of The Twentieth Century 184 (Valentine.M. Moghadam ed., 1996); Monica Boyd, Family and Personal Networks in International Migration: Recent Developments and New Agendas, 23 INT'L MigRATION REV. 638 (1989); Zillah Eisenstein, Stop Stomping on the Rest of Us: Retrieving Publicness from the Privatization of the Globe, 4 IND. J. GLOBAL LEGAL STUD. 59 (1996).
} 
underscore the interdependence of national processes in the global arena.

Nationally oriented research draws attention to the continued salience of local societies and domestic organizational structures. But local economies, including local political and cultural formations, are increasingly affected by globalization; as a result, the appropriate unit of analysis must combine both the local and the global. We can only claim to understand specific global developments when we know the diverse national contexts in which lawyers work and live. Cross-national research can provide a better understanding on issues of convergence or divergence and expands our understanding of potential similarities and differences regarding inequality and diversity in the practice of law. Such research may provide valuable insights into processes and causal pathways across multiple (e.g., economic, political, organizational, and individual) dimensions.

Empirically oriented survey work on the legal profession is still highly concentrated in North America. There is too little cross-national empirical research on which we could rely to develop our understanding of the organization and management of legal practice in other countries and the impact on lawyers'-and particularly on female lawyers'-work and careers. ${ }^{25}$ Survey research and narratives are needed to study issues of inequality, diversity, and changes over time. Unless we undertake analyses in closely coordinated ways and beyond nation-states, for example, by using parallel research designs, it will be difficult to draw meaningful conclusions about the legal profession and gender relations across national settings.

To understand global processes, it is important to investigate the deeper structures in which law is socially, culturally, politically, and economically embedded. Social and cultural categories (e.g., gender, race, ethnicity, social status) and other dimensions of identity interact on multiple and simultaneous levels, all of which contribute to forms of inequality and discrimination. Yet, these categories do not work independently of one another; instead they interrelate and thereby create a system of inequality that reflects an intersection of multiple forms of disadvantage or social exclusion. Cross-cultural comparisons are challenging because of the many complexities involved in identifying multidimensional conceptualizations that explain how socially constructed categories of difference interact to create a social hierarchy.

The contributions to this symposium strongly suggest that it is important to examine national settings by trying to integrate individual,

25. See generally LAWYERS IN SOCIETY: AN OVERview (Richard Abel \& Philip Lewis eds., 1996); MARY Jane MOSSMan, The FIRST WOMEn LaWYERS: A CoMParative STUdy OF GENDER, LAW AND THE LEGAL PROFESSIONS (2006); Plickert \& Hagan, supra note 11. 
interactional, and institutional levels of analysis. Doing so will enable us to understand social contexts and attitudes toward gender hierarchies as well as the challenges of overcoming local beliefs and expectations. How and whether transitions from gender inequality to greater equity in the national and global legal professions will occur remains an important empirical and normative agenda. 
